\title{
MENINGKATKAN KEMAMPUAN GURU DALAM MENYUSUN PERENCANAAN PEMBELAJARAN MELALUI PEMBINAAN KOLABORATIF
}

\author{
Nani Suryani \\ SD N Mancogeh, Jl. Cigeureung No. 22, Cipedes, Tasikmalaya, Indonesia \\ Email: nasaruana@gmail.com
}

\begin{abstract}
Lesson plan must match to the predetermined educational targets. As subjects of planning, teachers are required to be able to arrange various teaching programs as approaches and methods to be used. Efforts that can be made to improve the ability of teachers to develop lesson plans are collaborative coaching. This study aims to increase the willingness and ability of teachers in developing syllabus and lesson plans (RPP) through collaborative coaching. The data source come from the instrument that is delivered to all teachers at SDN Mancogeh, Cipedes District, Tasikmalaya City. Data analysis are processed descriptively and qualitatively. Then, it is consulted with the success criteria to find out whether collaborative coaching can improve the ability and willingness of teachers in making syllabus and lesson plans or not. Based on the results of data analysis, the conclusion is that collaborative coaching can improve the ability of teachers to develop syllabus and lesson plans.
\end{abstract}

Keywords: Lesson Plans, Collaborative Coaching

\begin{abstract}
ABSTRAK
Perencanaan pembelajaran harus sesuai dengan target pendidikan yang telah ditentukan. Guru sebagai subyek dalam perencanaan dituntut untuk dapat menyusun berbagai program pengajaran sebagai pendekatan dan metode yang akan digunakan. Upaya yang dapat dilakukan untuk meningkatkan kemampuan guru dalam menyusun rencana pembelajaran adalah dengan pembinaan kolaboratif. Penelitian ini bertujuan untuk meningkatkan kemauan dan kemampuan guru dalam membuat pengembangan silabus dan rencana pelaksanaan pembelajaran (RPP) melalui pembinaan kolaboratif. Sumber data berasal dari instrumen yang disampaikan kepada semua guru di SDN Mancogeh Kecamatan Cipedes Kota Tasikmalaya. Analisis data dilakukan dengan menggunakan analisis deskriptif dan kualitatif. Selanjutnya disesuaikan dengan kriteria keberhasilan untuk mengetahui apakah pembinaan kolaboratif dapat meningkatkan kemampuan dan kemauan guru dalam membuat silabus dan RPP. Berdasarkan hasil analisis data diperoleh kesimpulan bahwa pembinaan kolaboratif dapat meningkatkan kamampuan guru dalam membuat pengembangan silabus dan rencana pelaksanaan pembelajaran.
\end{abstract}

Kata Kunci: Perencanaan Pembelajaran, Pembinaan Kolaboratif

Cara sitasi: Suryani, N. (2021). Meningkatkan Kemampuan Guru dalam Menyusun Perencanaan Pembelajaran melalui Pembinaan Kolaboratif. J-KIP (Jurnal Keguruan dan IImu Pendidikan), 2 (1), 65-70. 


\section{PENDAHULUAN}

Peraturan Menteri Pendidikan Nasional Republik Indonesia Nomor 16 tahun 2007 tentang Standar Kualifikasi Akademik dan Kompetensi Guru menyebutkan bahwa kompetensi guru sekolah dasar meliputi kompetensi pedagogik, kompetensi kepribadian, kompetensi sosial, dan kompetensi profesional. Kompetensi pedagogik adalah kemampuan guru dalam mengembangkan kurikulum yang terkait dengan mata pelajaran pada kelas yang diampu. Kompetensi pedagogik tersebut sangat relevan dengan salah satu kewajiban guru sesuai dengan Peraturan Pemerintah Nomor 74 tentang Guru pasal 52 ayat (1) mencakup kegiatan pokok guru yaitu merencanakan pembelajaran, melaksanakan pembelajaran, menilai hasil pembelajaran, membimbing dan melatih peserta didik serta melakukan tugas tambahan yang melekat pada pelaksanaan tugas pokok. Selain itu kewajiban pendidik adalah menciptakan suasana pembelajaran yang aktif, kreatif, efektif dan menyenangkan.

Kegiatan pembelajaran adalah suatu kondisi yang dengan sengaja diciptakan untuk proses belajar mengajar pada peserta didik di kelas, dalam kegiatan ini sangat diperlukan peran guru untuk mencapai tujuan yang diharapkan. Mengingat pentingnya kegiatan pembelajaran maka guru perlu merancang sebaik mungkin, sehingga materi yang diberikan bermanfaat bagi siswa. Oleh karena itu, perlu adanya alternatif atau inovasi baru dari pendidik dalam proses pembelajaran (Afifah, et. al. 2020). Perencanaan atau rancangan ini merupakan proses penyusunan sesuatu yang akan dilaksanakan untuk mencapai tujuan yang telah ditentukan. Dalam perencanaan pembelajaran harus disesuaikan dengan target pendidikan yang telah ditentukan. Guru sebagai subyek dalam perencanaan dituntut untuk dapat menyusun berbagai program pengajaran sebagai pendekatan dan metode yang akan digunakan.

Perencanaan pembelajaran (instruction design) adalah keseluruhan proses analisis kebutuhan dan tujuan belajar serta pengembangan sistem penyampaiannya untuk memenuhi kebutuhan dan mencapai tujuan belajar, termasuk didalamnya pengembangan paket pembelajaran dan kegiatan mengevaluasi program dan hasil belajar (Depdiknas, 2004). Kegiatan pembelajaran di sekolah harus mengacu pada kurikulum yang sudah dikembangkan sekolah dan berpedoman pada Undang-Undang Republik Indonesia Nomor 20 Tahun 2003 tentang Sistem Pendidikan Nasional dan Peraturan Pemerintah Republik Indonesia Nomor 19 Tahun 2005 tentang Standar Nasional Pendidikan. Kurikulum yang dilaksanakan sekarang adalah Kurikulum Tingkat Satuan Pendidikan (KTSP) yang lebih operasional yang disusun dan dilaksanakan oleh masing-masing satuan pendidikan /sekolah.

Prinsip ini diimplementasikan untuk memberdayakan daerah dan sekolah dalam merencanakan, melaksanakan dan mengelola serta menilai pembelajaran sesuai dengan kondisi dan aspirasi. Dalam pelaksanaannya ditandai dengan keberagaman silabus yang dikembangkan oleh sekolah masing-masing sesuai dengan karakteristik sekolahnya. Silabus merupakan penjabaran standar kompetensi dan kompetensi dasar ke dalam materi pokok, kegiatan pembelajaran dan indikator pencapaian kompetensi untuk penilaian, alokasi waktu dan sumber belajar.

Dalam implementasinya silabus dijabarkan dalam rencana pelaksanaan pembelajaran, dilaksanakan, dievaluasi, dan ditindaklanjuti oleh masing-masing guru. Selain itu, silabus harus dikaji dan dikembangkan secara berkelanjutan dengan memperhatikan masukan hasil evaluasi belajar, evaluasi proses (pelaksanaan pembelajaran), dan evaluasi rencana pelaksanaan pembelajaran. Silabus bermanfaat sebagai pedoman dalam pengembangan pembelajaran lebih lanjut, seperti pembuatan rencana pembelajaran, pengelolaan kegiatan pembelajaran dan pengembangan sistem penilaian.

Pembelajaran dan pengembangannya sepenuhnya menjadi tugas dan kreativitas dari guru yang mengajar di kelas, guru dituntut memiliki kreativitas yang tinggi karena dengan menggunakan Kurikulum Tingkat Satuan Pendidikan (KTSP) sekolah diberi keleluasaan untuk membuat strategi pembelajaran sendiri dalam menyampaikan mata pelajaran sesuai dengan kurikulum yang telah 
ditentukan kepada siswa disesuaikan dengan situasi dan kondisi di sekolah masing-masing. Untuk itu masing-masing sekolah berusaha untuk meningkatkan kualitas pembelajaran dengan sebaikbaiknya tanpa mengurangi esensi dan substansi dari kurikulum yang ada (Muslich, 2007).

Di dalam pembelajaran ada 3 komponen yang harus dikembangkan dan saling keterkaitan yaitu guru, siswa dan proses pembelajaran. Dari pihak guru adalah guru harus terlebih dahulu membuat perencanaan pembelajaran yang matang mulai dari membuat program tahunan, program semester, dan program harian yang berupa Rencana Pelaksanaan Pembelajaran (RPP) disamping harus menguasai materi yang akan diajarkan, metode-metode mengajar dan bisa menguasai kelas serta membuat alat evaluasi. Dari pihak siswa kesiapan menerima pelajaran, kedisiplinan dan kesungguhan, sedangkan proses pembelajaran adalah ada suatu sinergi antara guru, murid, metode dan model pembelajaran yang tepat dari materi kompetensi yang akan diajarkan.

Untuk mencapai hal tersebut guru harus mengembangkan silabus dan Rencana Pelaksanaan Pembelajaran (RPP), hal ini menuntut kesiapan guru secara maksimal. Dengan demikian kompetensi yang ingin dicapai dalam perencanaan bisa tercapai dengan baik. Berdasarkan hasil pemantauan melalui supervisi akademik dan hasil dari penelitian eksplorasi di SDN Mancogeh Kecamatan Cipedes Kota Tasikmalaya masih ditemukan guru yang mengajar belum mengkaji ulang pengembangan silabus dan pengembangan Rencana Pelaksanaan Pembelajaran (RPP) untuk kompetensi yang akan diajarkan, sehingga dalam pelaksanakan proses pembelajaran tidak terrencana dengan baik ,karena mungkin terjadi materi yang berulang-ulang diberikan pada siswa, sedangkan kompetensi yang lain tidak tersampaikan secara keseluruhan.

Ada sebagian guru memiliki rencana pembelajaran lengkap, tetapi dengan cara memfotokopi dari sekolah lain yang situasi dan kondisinya berbeda, baik guru, siswa maupun sarana dan prasarananya, karena yang membuat orang lain pemikiran dan ide-idenya juga bisa saja berbeda, sehingga rencana pembelajaran yang telah ada tidak bisa dilaksanakan dengan sebaikbaiknya. Berikut hasil rekapitulasi supervisi akademik aspek administrasi guru kelas pada tahun pelajaran 2019/2020.

Sebagai dampak dari tidak/belum disusunnya rencana pembelajaran secara mandiri maka metode dan model pembelajaran yang akan digunakan pun tidak terencana dengan baik, dan metode yang digunakan tanpa adanya persiapan khusus. Pada umumnya digunakan metode ceramah yang mengakibatkan siswa menjadi pasif, kurang antusias, mengantuk, dan ada pula yang mengerjakan mata pelajaran lain. Sedangkan bagi yang memfotocopi silabus dan Rencana Pelaksanaan Pembelajaran dari sekolah lain sebagian besar tidak bisa diterapkan, karena situasi dan kondisinya berbeda. Padahal dengan diterapkannya Kurikulum Tingkat Satuan Pendidikan (KTSP), sekolah diberi otoritas penuh untuk melaksanakan kurikulum disesuaikan dengan situasi dan kondisi sekolah masing-masing, tanpa merubah substansi dan esensi dari kurikulum yang telah disusun oleh Badan Standar Nasional Pendidikan (BSNP)

Masalah yang telah diuraikan diatas harus segera diatasi. Berkenaan dengan hal tersebut maka peneliti melakukan pembinaan dengan cara Kolaboratif dengan alasan cara ini paling tepat, karena adanya interaksi antara guru dan pengawas sekolah mempunyai kedaulatan yang seimbang, masing-masing memiliki kewajiban. Pengawas sebagai membina, memiliki kewajiban untuk melaksanakan pembinaan terhadap guru dalam hal ini membina perencanaan pembelajaran, sedangkan guru memiliki tanggung jawab untuk membuat perencanaan pembelajaran sebagai salah satu dari pemenuhan standar kompetensi guru yaitu kompetensi profesional dan kompetensi pedagogik, dengan demikian masing-masing melaksanakan kewajiban tanpa ada keterpaksaan dalam melaksanakannya.

Berdasarkan latar belakang tersebut, maka penulis merumuskan masalah sebagai berikut "Apakah pembinaan kolaboratif dapat meningkatkan kemampuan dan kemauan guru dalam menyusun perencanaan pembelajaran?". 


\section{METODE PENELITIAN}

Jenis penelitian ini adalah Penelitian Tindakan Kelas (PTK). Arikunto (2009) mengemukakan bahwa Penelitian Tindakan Kelas merupakan suatu pencermatan terhadap kegiatan belajar berupa sebuah tindakan, yang sengaja dimunculkan dan terjadi dalam sebuah kelas secara bersama. PTK merupakan penelitian yang dilakukan oleh guru di kelasnya sendiri dengan cara merencanakan, melaksanakan, dan merefleksikan tindakan secara kolaboratif dan partisipatif dengan tujuan memperbaiki kinerja guru sehingga hasil belajar siswa dapat meningkat. Penelitian tindakan kelas yang digunakan dalam penelitian ini mengacu pada Model Kemmis \& McTaggrat yang terdiri dari empat komponen, yaitu perencanaan (planning), tindakan (acting), pengamatan (observing) dan refleksi (reflecting).

Sesuai dengan fokus permasalahan maka yang menjadi subjek dalam penelitian ini adalah guru-guru di SDN Mancogeh Kecamatan Cipedes Kota Tasikmalaya.

\section{HASIL DAN PEMBAHASAN}

Dalam penelitian ini, peneliti memilih model Pembinaan Kolaboratif dengan harapan terjadi kontrak antara kepala sekolah dan guru, karena dalam pola Pembinaan Kolaboratif ada kedaulatan yang seimbang antara kepala sekolah dan guru, yang memiliki tanggung jawab masing-masing sama-sama sedang. Dalam pandangan Kolaboratif ini, perilaku pokok kepala sekolah mencakup : mendengarkan, mempresentasikan, memecahkan masalah dan negosiasi. Dalam pembahasan ini peneliti sampaikan langkah-langkah yang telah dilakukan dalam rangka Pembinaan guru tentang penyusunan pengembangan silabus dan rencana pelaksanaan pembelajaran.

Dengan mendengarkan semua kesulitan-kesulitan yang dihadapi oleh guru, yaitu tentang penyusunan pengembangan silabus dan pengembangan Rencana Pelaksanaan Pembelajaran (RPP) guru-guru merasa mendapatkan perhatian,dan kesulitannya didengar sehingga menjadi lebih terbuka untuk mengemukakan kesulitannya masing-masing. Kesulitan-kesulitan yang dihadapi guru diinventarisir dan diolah, setelah itu Kepala sekolah mempresentasikan tentang pentingnya membuat perencanaan pembelajaran sendiri yang sesuai dengan kompetensi yang ingin dicapai agar tahu persis apa yang akan dilakukan sesuai dengan situasi dan kondisi serta sarana dan prasarana yang tersedia. Dengan demikian guru menyadari kekeliruannya selama ini, yang hanya memfotokopi silabus dan RPP dan itupun hanya dikumpulkan pada wakil Kepala sekolah Sekolah urusan kurikulum, belum dijadikan sebagai pedoman dalam mengajar.

Setelah guru menyadari kekeliruannya selama ini,mereka ingin mencoba menyusun pengembangan silabus dan RPP sendiri dan bersedia untuk diadakan Pembinaan secara klasikal dan berdasarkan kesepakatan diadakan dua kali yang pertama tentang penyusunan pengembangan silabus dan yang kedua penyusunan pengembangan rencana pelaksanaan pembelajaran.

Data hasil penelitian ini diketahui bahwa pembuatan perencanaan pembelajaran dilaksanakan melalui 2 siklus yaitu :

A. Siklus I, dilaksanakan dalam 2 kali pertemuan, pada pertemuan 1 setelah selesai diadakan refleksi, dan diperoleh data bahwa penentuan materi ajar, menentuan indikator keberhasilan dan menentukan sumber belajar masih kurang dari target keberhasilan pada penelitian ini, maka untuk materi yang masih kurang dilanjutkan pada pertemuan 2, setelah selesai pertemuan 2 diadakan refleksi untuk menentukan apakah masih perlu ada pertemuan 3 atau tidak.

Terdapat peningkatan yaitu tentang materi ajar dari $47 \%$ menjadi $84 \%$, Kegiatan pembelajaran meningkat dari $16 \%$ menjadi $68 \%$, Indikator dari $26 \%$ menjadi $74 \%$, jenis penilaian dari $47 \%$ menjadi $84 \%$. Dalam penelitian ini, peneliti mentargetkan kriteria keberhasilan adalah $75 \%$, berarti pada siklus I pertemuan 2 ini kriteria keberhasilan yang sudah ditetapkan sudah tercapai, maka pada pertemuan kedua ini untuk penyusunan pengembangan silabus dianggap sudah selesai dari yang direncanakan 2 kali pertemuan. Untuk selanjutnya 
diteruskan pada siklus II tentang penyusunan pengembangan Rencana Pelaksanaan Pembelajaran (RPP).

B. Siklus II dilaksanakan dalam 2 kali pertemuan, pada pertemuan 1 setelah selesai pengamatan diadakan refleksi, dan diperoleh data bahwa :

Dalam kegiatan inti yaitu belum merencanakan kegiatan yang bisa mengaktifkan siswa dalam hal ini menentukan model pembelajaran, demikian juga dalam menentukan aspek penilaian masih ditemukan belum adanya kesesuaian antara materi pembelajaran dengan bentuk soal yang dibuat termasuk dalam menentukan skore penilaian. Dengan telah ditemukan kekurangan pada pertemuan 1 ini, maka untuk materi yang masih kurang dilanjutkan pada pertemuan 2, setelah selesai pada pertemuan 2 hasilnya dikumpulkan, diteliti dan dianalisa, setelah itu diadakan refleksi untuk menentukan pada tahap berikutnya.

Pengembangan kegiatan inti dalam hal ini menentukan model pembelajaran sudah ada peningkatan yaitu : dari $68 \%$ meningkat menjadi $100 \%$ dan aspek penilaian dari $68 \%$ meningkat menjadi $89 \%$, tujuan pembelajaran meningkat dari $47 \%$ menjadi $84 \%$, materi ajar dari $47 \%$ menjadi $89 \%$. Target pencapaian hasil yang ditetapkan oleh peneliti sebanyak $75 \%$ guru-guru mampu membuat Rencana Pelaksanaan Pembelajaran (RPP) sendiri sudah tercapai. Dengan demikian pada siklus II pertemuan kedua ini dianggap telah selesai.

Berdasarkan hasil penelitian maka diperoleh hasil bahwa upaya yang digunakan oleh Kepala sekolah Sekolah agar guru-guru sebelum mengajar membuat perencanaan pembelajaran adalah dengan cara memberikan Pembinaan dan cara yang digunakan oleh kepala sekolah adalah cara pembinaan dengan Kolaboratif, karena antara Kepala sekolah dan guru sama-sama memiliki tanggung jawab. Kepala sekolah memberikan motivasi agar sebelum mengajar sudah menyusun pengembangan pembelajaran yang dibuat sendiri sehingga pada pelaksanaan pembelajaran lebih percaya diri, terprogram dan sesuai dengan situasi dan kondisi sekolah serta sarana dan prasarana yang tersedia serta untuk memenuhi tuntutan kompetensi profesionalisme dan kompetensi pedagogik seorang pendidik,dengan demikian tujuan akhir adalah prestasi siswa baik.

Dari hasil penelitian ini diperoleh adanya peningkatan kemampuan guru-guru dalam membuat perencanaan pembelajaran meliputi penyusunan pengembangan silabus dan Rencana Pelaksanaan Pembelajaran (RPP) setelah diberikan pembinaan secara Kolaboratif oleh Kepala sekolah. Sejalan dengan hasil penelitian Hanifah (2017) dan Effendi (2019) yang menyatakan adanya peningkatan kemampuan guru-guru dalam membuat perencanaan pembelajaran meliputi penyusunan pengembangan silabus dan Rencana Pelaksanaan Pembelajaran (RPP) setelah diberikan pembinaan secara Kolaboratif oleh Pengawas.

\section{KESIMPULAN}

Berdasarkan analisis data penulis mengambil kesimpulan yaitu terdapat peningkatan kemampuan guru dalam menyusun perencanaan pembelajaran sebelum ada pembinaan dan setelah dilaksanakan pembinaan yaitu pada pengembangan kegiatan inti dalam hal ini menentukan model pembelajaran sudah ada peningkatan yaitu : dari $68 \%$ meningkat menjadi $100 \%$ dan aspek penilaian dari $68 \%$ meningkat menjadi $89 \%$, tujuan pembelajaran meningkat dari $47 \%$ menjadi $84 \%$, materi ajar dari $47 \%$ menjadi $89 \%$. Target pencapaian hasil yang ditetapkan oleh peneliti sebanyak $75 \%$ guru-guru mampu membuat Rencana Pelaksanaan Pembelajaran (RPP) sendiri sudah tercapai. Dengan demikian pada siklus II pertemuan kedua ini dianggap telah selesai

Penulis menyampaikan saran kepada para guru agar selalu mengutamakan penyusunan perencanaan pembelajaran karena dengan perencanaan yang matang maka pembelajaran akan maksimal. Kepada para kepala sekolah agar selalu melaksanakan perannya sebagai supervisor dengan melaksanakan kegiatan supervisi akademik agar dapat diketahui permasalahan dan kesulitan yang dihadapi guru. 


\section{REKOMENDASI}

Rekomendasi dari penelitian ini adalah agar para pengawas selalu mengadakan pembinaan penyusunan rencana pelaksanaan pembelajaran dan supervisi akademik (Penyusunan RPP dan pelaksanaan KBM) secara terprogram baik itu dengan pembinaan kolaboratif maupun dengan cara lainnya.

\section{UCAPAN TERIMAKASIH}

Penulis mengucapkan terima kasih kepada guru-guru di SDN Mancogeh yang telah mendukung terhadap pelaksanaan penelitian ini.

\section{DAFTAR PUSTAKA}

Afifah, A. N., Ilmiyati, N \& Toto. (2020). Pengaruh Model Project Based Learning (PjBL) dengan Pendekatan STEM Terhadap Penguasaan Konsep dan Keterampilan Berpikir Kritis Siswa. J-KIP (Jurnal Keguruan dan IImu Pendidikan), 1 (2), 33-40.

Arikunto, S. (2009). Manajemen Penelitian. Jakarta: Rineka Cipta.

Badan Standar Nasional Pendidikan. (2007). Peraturan Menteri Pendidikan Nasional Republik Indonesia Nomor 16 Tahun 2007 tentang : Standar Kualifikasi Akademik dan Kompetensi Guru, Jakarta: KEMENDIKBUD.

Departemen Pendidikan Nasional. (2004). Perencanaan Pembelajaran. Jakarta : Direktorat Jenderal Pendidikan Dasar dan Menengah Direktorat Tenaga Kependidikan.

Efendi, R. (2019). Meningkatkan Kemampuan Guru Dalam Menyusun Perencanaan Pembelajaran Melalui Pembinaan Kolaboratif Bagi Guru SMA Negeri 1 Putri Betung Kabupaten Gayo Lues. Jurnal Serambi Edukasi, 3 (1), 19-28.

Hanifah. (2017). Meningkatkan Kemampuan Guru Dalam Menyusun Perencanaan Pembelajaran Melalui Pembinaan Kolaboratif Bagi Guru Kelas V Di Dabin II Unit Pendidikan Kecamatan Gedangan. Pedagogia : Jurnal Pendidikan, 6 (2), 194-211.

Muslich, M. (2007). KTSP Kurikulum Tingkat Satuan Pendidikan Dasar Pemahaman dan Pengembangan. Seri Standar Nasional Pendidikan, Pedoman Bagi Pengelola Lembaga Pendidikan, Pengawas Sekolah, Pengawas Sekolah, Komite Sekolah, Dewan Sekolah dan Guru. Jakarta : Bumi Aksara 